\title{
Impact of Female Executive on Investment Efficiency of Listed Companies in Shanghai Stock Market: A Case of Over-Investment
}

\author{
Mengyi Fan, Wasin Phromphitakkul \\ School of Management, Shinawatra University, Banhkok, Thailand \\ Email: fmyyxy1994@163.com,wasin.p@siu.ac.th
}

How to cite this paper: Fan, M. Y., \& Phromphitakkul, W. (2021). Impact of Female Executive on Investment Efficiency of Listed Companies in Shanghai Stock Market: A Case of Over-Investment. Modern Economy, 12, 1119-1136.

https://doi.org/10.4236/me.2021.126059

Received: May 11, 2021

Accepted: June 25, 2021

Published: June 28, 2021

Copyright (c) 2021 by author(s) and Scientific Research Publishing Inc. This work is licensed under the Creative Commons Attribution International License (CC BY 4.0)

http://creativecommons.org/licenses/by/4.0/

(c) (i) Open Access

\begin{abstract}
The purpose of this study is to analyze the relationships between the presence of female in top management teams and over-investment behavior of listed companies. This study draws on Richardson's (2006) model and selects A-share listed companies from the Shanghai Stock Exchange from 2017 to 2018 as a research sample. After eliminating the financial listed companies and missing data samples, 725 sample companies were used for statistical analysis. The result shows that 1 ) the existence of female top management can effectively inhibit the occurrence of over-investment behavior of the company. 2) The higher the proportion of female senior executives, the less likely the listed company's over-investment behavior will occur. The research in this paper will provide new ideas for the effectiveness of China's listed companies to strengthen the internal governance mechanism, provide a broader direction for the study of investment theory, and also promote the transformation of the company's human capital management practices.
\end{abstract}

\section{Keywords}

Female Executives, Investment Efficiency, A Listed Company

Over-Investment

\section{Introduction}

Throughout the world, financing decisions, investment decisions and profit distribution decisions are always the three major financial decisions of listed companies. A company's financing behavior depends to a considerable extent on investment decisions, at the same time, the amount of investment income directly determines the company's profit distribution and dividend payment behavior, so investment decisions are at the core of the three major financial decisions. From 
a macroeconomic perspective, investment is an important factor driving the overall economic development, our research on corporate investment behavior can reflect the law of cyclical changes in the economy. For a single company, investment is the foundation of future cash flow growth of the company, and the level of investment efficiency directly affects the growth of the company. We need to maximize the value of the company by improving the investment efficiency.

In China, more and more female members are involved in the management of the company, and women are gradually appearing in the executive management of the company. Female executive positions inject fresh power into the executive team of the company. They provide a new perspective for corporate governance and strategic decision-making with their own prudence and sensitivity. Their practical, pragmatic and responsible sense can better manage the details and beautifully complete their work. At the same time, they have good communication skills and affinity characteristics. Through the integration with men, the efficiency of the whole company can be improved. The driving factor for forward development cannot be ignored.

\section{Statement of the Problem}

The Previous literature has analyzed the causes of excessive investment behavior theoretically and empirically from the aspects of behavioral finance, such as entrusted-agent theory, information asymmetry theory, financing constraint, government intervention and behavioral monopoly, management overconfidence, jealousy and herd effect. And from corporate governance, accounting information quality, debt financing, cash dividends and other aspects to explore the constraints of excessive investment behavior. Jensen and Meckling (1976) explained the over-investment behavior by a conflict of interest between creditors and shareholders. He assumes that the interests of shareholders and managers are the same, and managers represent the will of shareholders. Pan and Jin (2003) point out that the development of China's securities market is not mature, compared with developed countries, equity financing companies and investors for project investment profit expectations of existing information asymmetry is more serious, with shares in listed companies in China under the special mechanism of different rights (Pan \& Jin, 2003), equity financing companies excessive investment behavior are more likely to occur. In the past, gender research in corporate management focused on a descriptive discussion of successful female entrepreneurs. In recent years, more studies have been conducted on the relationship between gender diversity of boards of directors and top management teams and corporate performance, but the specific aspects of the impact of performance are uncertain. A few scholars studied by Chinese companies in emerging markets the gender of the board of directors of the heterogeneity problems, the empirical results also proved that the female members in the TMT can prevent more risk-taking. 
In this paper, the influence of female executive positions on corporate performance is specifically reflected in the behavior of investment. It believes that the advantages of relevant knowledge, perspective, creativity and judgment brought by heterogeneous groups can improve the quality of investment decisions. Through the hypothesis of using empirical research to test, a new perspective on the over-investment behavior of listed companies.

\section{Research Objectives}

1) To study the influence of the presence of female executives at the top management teams on the over-investment behavior of listed companies.

2) To test the relationship between the proportion of female executives in senior positions and the over-investment behavior of listed companies.

\section{Practical of the Significance}

1) In the emerging economies, we need to use the power of female's top management to play the role of female talents to improve the company's governance structure. Companies need to pay more attention to female at the senior position. The company should desalt the sense of male control at the top, achieve real equality between men and women in the construction of corporate culture, and realize that the perfect combination of male and female employees will bring greater development to the company, expand the career field of female, and provide better development space for female to work.

2) When selecting employees, we should give female and male a fair chance to compete. On the promotion of position, company should treatability and strength equally, put aside the sexist belief that men are more suitable for managers, and let the most suitable people be promoted.

3) Compared with the developed countries in the world, under the circumstance that competitiveness of the female top management is obviously lagging behind in China, the company governance policies should strengthen the gender mainstreaming thought. In the internal system charter of the company, it is necessary to increase the relevant terms and conditions of female executives, and clarify the relevant rights and obligations, and stipulate the appropriate proportion of female personnel in the board of directors and the board of supervisors according to their own development needs. This not only contributes to the reform of the internal structure of the company, but also is an important measure to adapt to economic development and to be in line with international standards.

\section{Literature Review}

In this chapter, the author presents information related to the topic. The information also used as secondary data to support the ideas of the current research. The author reviewed books, texts, academic journals, and statistic and summarized by each category. 


\subsection{Related Theory}

\subsubsection{Over-Investment}

The origin of over-investment at home and abroad originated from Jensen \& Meckling's (1976) "Agent Cost Theory" in his classic paper "Corporate Theory: Management Behavior, Agency Cost and Ownership Structure Literature", pointing out that professional managers may be in the company's business activities. In order to maximize self-interest, conduct self-interested operations, engage in activities that harm the interests of shareholders, such as: on-the-job consumption, over-investment, slack work, etc. Later, many scholars conducted a large number of in-depth studies on excessive investment. Jensen (1986) believed that excessive investment was the inefficient investment behavior of companies, that is, the free cash in companies was invested in projects with the net present value of investment $<0$.

\subsubsection{Free Cash Flow Theory}

Jensen (1986) puts forward the theory of free cash flow. This theory believes that the corresponding agency cost is caused by capital flow due to the interest issues and consulting differences between the company's stockholders, corporate leaders, and senior management. Company leaders and senior managers can use capital flows to participate in some high-return projects to meet their own interests, and have a tendency to over-invest in the establishment of a "manager empire". This kind of motivation encourages managers to use more disposable corporate internal funds for corporate project investment.

\subsubsection{Information Asymmetry}

The existence of asymmetric information is an objective factor that affects the non-efficient investment of enterprises. Myers \& Majluf (1984) found that when an enterprise's external financing is higher than its internal financing, it is more likely to cause under-investment. When the company conducts financing, due to the existence of information asymmetry, the stock price may be overvalued or undervalued. If the stock is undervalued, the loss will be greater than the benefit of investment, and the company will choose to give up the investment project with positive NPV, resulting in the behavior of under-investment. On the contrary, if stocks are overvalued, companies will be willing to issue more shares, or even use the funds raised for investment projects with a net present value less than zero, resulting in blind investment.

\subsubsection{Theory of Resource Reliance}

Pfeffer and Salancik (1978) were the first to put forward his opinion on the resource dependence theory, and they all said the organization to continue its own survival and development, must be obtained from the open environment, the resource needed or exchanged with specific resources and environment, organization's ability to obtain and maintain resources determines the organization's survival or not, and the organization of the key is to keep good relationship with important resource provider, so as to improve enterprise value. As a unique re- 
source of enterprises, senior executives play an irreplaceable role in enterprises. Executives as managers of enterprises, can bring resources for enterprises from the following three aspects: provides environment and competitors' information, and provide strategic and operating from the Angle of professional technical support; create good internal and external information communication channels for enterprises; make the behavior of the enterprise in the external environment more legitimate, so as to help the enterprise can more easily obtain support from the resource providers in the external environment.

\subsubsection{Behavioral Finance Theory}

For a long time, financial research has assumed that investors are rational economic people based on efficient market theory, that is, people are driven by self-interest and are capable of making rational judgments and decisions even under uncertain circumstances. However, the facts before our eyes are sometimes far from each other. More and more market anomalies make people have to suspect that the perpetrators have irrational tendencies. So behavioral finance, which combines psychology and sociology, came into being. Behavioral finance, as a cross-science, fully considers the influence of market actors' confidence and emotions and other psychological factors, studies investors' behavioral decisions closer to the market, and makes up for the shortcomings of traditional financial theories.

Investors are overconfident. On the one hand, even if managers rationally reject investment projects that investors believe have profit space, leading to investors' selling of the company's shares and the decline of the stock price, the managers, under the pressure of external investors, will go against their original intention to invest in projects that are not conducive to maximizing the value of the company. On the other hand, irrational investors' over-optimism for certain projects in the market may mislead corporate managers to believe that the market has a more accurate judgment of these investment projects, and the effect of "herd effect" makes managers invest in projects with negative net present value. In addition to the above situations, the irrationality of managers and managers also shows that they refuse to admit their own failures. When an enterprise is implementing an investment, it has shown that the net present value is negative in the process, but the managers are unwilling to give up the project. They want to give people the impression that they made the right decision at the beginning, and will even continue to make additional investment.

\subsubsection{Upper Echelons Theory}

Hambrick and Mason (1984) put forward the theory of upper echelon, on the premise of limited rationality, it is considered that the top management team is not homogeneous. The personal background characteristics of the manager will affect the values, perceptions and cognition of managers, risks and reference, etc., which affects the manager's way of thinking and behavior choice, which in turn affects the company's strategic choice and corporate performance. The 
theory of upper echelon is based on two important premises, which are: 1) The psychological characteristics of the managers of the top management team will ultimately affect the strategic selection and decision-making process of the enterprise; 2) The demographic characteristics of top management teams are considered to be the external manifestation of the psychological characteristics of top executives. At the same time, it is easy to collect and conduct quantitative research.

Hambrick (1994) further revised the theoretical foundation model of the upper echelon and summarized the basic theoretical concept system of the top management team, including the structure, composition, incentives and processes of the top management team. The strategic decision-making process of the top management team is essentially the process of integration of the thoughts and behaviors of the top management team members.

\subsection{Related Research}

\subsubsection{Female Executives}

It's studied the fortune 500 companies from 1996 to 2000 and found that the companies with the highest proportion of female managers had a $35.1 \%$ higher return on equity and a $34 \%$ higher return on shareholders than those with the lowest proportion. McKinsey, a management consulting company since 2007 for women "vital" series of research, the study found women executives more companies generally in terms of "health" nine dimensions of performance is superior to other companies (in this case, the nine dimensions: leadership, culture and atmosphere, direction, ability, responsibility, coordination and control, motivation, innovation and learning, external guide). Smith et al. (2006) found that when a woman's qualifications are qualified for directorship or CEO positions, gender diversity at the top management will improve the company's financial performance, and it is necessary for the company to attract and recruit more capable women to the board or as a senior CEO. Gao and Zhang (2011) concluded that the efficiency of teamwork on the board of directors will be significantly improved when the number of female directors on the board exceeds three (Gao \& Zhang, 2011). Zhang, Guan and Guo (2011) used 14 listed banks in China as research samples to find that the work experience and educational background of female directors will have an impact on the board of directors. Appropriate increase in the proportion of female directors can improve the bank's performance. Zeng and $\mathrm{Wu}$ (2012) conducted research on the GEM of the Shenzhen Stock Exchange, pointing out that female executives' human capital contributes to the formation of a good innovation atmosphere, thus creating favorable conditions for technological innovation, especially in the telecommunications and technology industries. The role of executives in corporate technology innovation is extremely significant.

\subsubsection{The Influencing Factors of Company's Over-Investment}

1) Over-investment from the perspective of principal-agent theory 
Under the modern enterprise system, the separation of ownership and management rights leads to conflicts of interest between the principal and the agent. The client wants the agent to create more benefits for the due diligence of the contract, and the agent aims to maximize the risk of his own interests by taking as little risk responsibility as possible. Jensen (1986) pointed out that when enterprises have higher free cash flow, the resources that can be directly controlled by managers can be increased. At this time, managers will try to use free cash flow to invest and expand the scale of enterprises, and even invest in net present value. Projects to meet their own personal interests. In 1993, he studied the investment behavior of 1431 listed companies in the United States and found that many companies had excessive investment problems and damaged the value of the company. He believed that the company's excessive investment behavior failed to form an internal governance mechanism that effectively restricted management. As a result, the agency's agency behavior has led to a decline in the value of the company. He and Ding (2001) conducted an empirical study on the data of 397 listed companies in Shanghai stock market from 1999 to 2000. It was found that managers would over-invest in their own investment in non-profit projects. Based on the study of the relationship between promotion incentives and over-investment (Zhang et al., 2013), the study found that in state-owned and non-state-owned companies, managers with different background characteristics also have different effects on promotion and over-investment.

2) Over-investment based on overconfidence of TMT (top management team)

A large amount of cognitive psychology literature believes that people are overconfident in the accuracy of their knowledge, thus overestimating their probability of success and underestimating the probability of failure in decision-making (Wolosin et al., 1973). Researches by domestic and foreign scholars have also shown that male executives are more likely to be overconfident than female executives (Zuckerman, 1994). Huang and Kisgen (2013) compared the differences in corporate financial decisions and investment decisions made by different executive genders, and found that male executives made acquisitions and issued debt more frequently than female executives. In addition, the announcement of acquisitions and debt issuance of companies where female executives are located is more profitable, leading to the conclusion that male executives are more overconfident than female executives.

Combining the above theories, female executives are less likely than male executives to develop overconfidence. When the free cash flow is sufficient, they will not overestimate the project profit or underestimate the project financing cost, thus inhibiting the over-investment of enterprises. In the absence of free cash flow, there will be no under-investment phenomenon.

\subsubsection{Overview of Countermeasures for Over-Investment}

Jensen (1986) puts forward the "debt control hypothesis". He believed that the rigid constraint of debt repayment can control the management's arbitrary con- 
trol over the free cash flow of the enterprise, thus inhibiting the management's excessive investment behavior. Li, Ma and Gao (2010) took the listed companies listed in A-share from 2004 to 2006 as samples to conduct an empirical study and found that current liabilities can well restrict managers' excessive investment behavior. Compared with current liabilities, non-current liabilities are less liquid and do not need to be returned in time. There is no pressure of short-term repayment of capital and interest, which increases managers' holding cash and provides a source of funds for excessive investment. Therefore, they are not binding on excessive investment.

Richardson (2003) found that in the case of large companies with independent directors, managers are less likely to over-invest. Li and Sun (2008) pointed out that the existence of professional committees on the board of directors can make independent directors truly independent and strengthen the role of independent directors in the board of directors, so that they can do their duty to help the company improve decision-making efficiency and restrict over-investment. The occurrence of behavior. Han (2011) pointed out that financial reports published by listed companies play a signaling role, and companies can reduce information asymmetry by improving the quality of their financial reports, so as to effectively regulate investment behaviors. Zheng (2010) analyzed that in China, the serious over-investment behavior of state-owned holding listed companies is caused by the monopoly of state-owned shares, and it is necessary to balance the rights of different shareholders through the reduction of state-owned shares to balance the rights of minority shareholders, so as to protect the interests of minority shareholders and reduce the over-investment behavior.

To sum up, domestic and foreign studies have concluded that excessive investment of companies can be restricted through debt control, independent director system, dividend policy, reduction of state-owned shares, accounting robustness and other aspects.

\section{Research Hypothesis}

\subsection{Put Forward the Hypothesis}

H1: Companies with female in the top management team are less likely to have over-investment than companies without female. That is to say, the existence of female executives can restrain the company's over-investment behavior to a certain extent.

$\mathrm{H} 2$ : There is a significant negative correlation between the proportion of female in top management team and the over-investment behavior of listed companies. In other words, the higher the proportion of female in senior positions, the less likely it is for listed companies to have over-investment.

\subsection{The Ways to Verify the Hypothesis}

1) In descriptive statistics analysis section, put the positive residual value calculated by the model (1) into the model (2) and the model (3) to test the in- 
fluencing factors of the company's over-investment behavior.

2) The main explanatory variables are tested by Pearson correlation coefficient method. If we find that the correlation coefficient between Female and OverINV is significant horizontally, and the correlation coefficient between PFSM and OverINV is significant horizontally, then our hypothesis has been initially confirmed.

3) Through collinearity diagnosis, test whether there is serious collinearity among explanatory variables in each model.

4) In the regression analysis section, we put the variables of the presence of female executives into the over-investment model (2) for regression analysis to verify the hypothesis 1 . In the model (3), the variable of the proportion of female executives in positions of office was replaced by the variable of the existence of female executives in the model (2) to judge its possible influence on the over-investment behavior of the company. Further verify Hypothesis 2.

\section{Research Methodology}

Since the current research focuses on the impact of the special perspective of female executives on the over-investment behavior of listed companies, the data and information from primary source of data is crucial. The author needs to have both wide and deep information from such sources. Thus, to fulfill the requirement of wide and deep data, the author designs the current research to be mixed methods research, Research methods include a combination of normative research and empirical research, statistics combined with mathematical models and the qualitative and quantitative research approach. This article mainly uses EXCEL 2019 for initial processing of samples and SPSS26.0 for empirical analysis of samples.

\subsection{Data Sources}

All data in this article comes from Wind database and CSMAR database.

About wind database:

As the market leader in China's financial information services industry, Wind is dedicated to providing accurate and real-time information, as well as sophisticated communication platforms for financial professionals. Hailed at home and abroad as the premier provider of China's financial information, Wind provides high-quality data frequently quoted by Chinese and international media, research reports, and academic papers.

About CSMAR database (China Stock Market \& Accounting Research Database):

Targeted at the precise research database, and with reference to the classification standards of CRSP (University of Chicago), COMPUSTAT (Standard \& Poor's) and other standard databases, the database is divided into stocks, companies, funds, bonds, derivatives, economic, industry, overseas, information se- 
ries databases. High-precision research database covering China's securities, futures, foreign exchange, macro, industry and other major economic and financial fields, is a basic tool for investment and empirical research.

\subsection{Data Collecting Method}

In sample selection, the main research objects are listed companies in Shanghai. In order to ensure the stability and validity of the sample data, this article makes the following data processing based on the original data in Table 1.

\subsection{Data Models}

In order to test the influence of female senior positions on the excessive investment behavior of listed companies, this paper builds the following model based on the analysis of relevant literature and the model of Richardson (2006):

$$
\begin{aligned}
& \mathrm{INV}_{t}=a_{0}+a_{1} \text { Growth }_{t-1}+a_{2} \mathrm{Le}_{t-1}+a_{3} \mathrm{Cash}_{t-1}+a_{4} \text { Age }_{t-1} \\
& +a_{5} \mathrm{Size}_{t-1}+a_{6} \mathrm{EPS}_{t-1}+a_{7} \mathrm{IN}_{t-1}+\Sigma \mathrm{Year}+\varepsilon \\
& \text { OverINV }_{t}=b_{0}+b_{1} \text { Female }_{t}+b_{2} \text { Scale }_{t}+b_{3} \mathrm{BIG}_{t}+b_{4} \text { Size }_{t} \\
& +b_{5} \mathrm{Cash}_{t-1}+b_{6} \mathrm{Lev}_{t-1}+\Sigma \text { Year }+\varepsilon \\
& \text { OverINV }_{t}=b_{0}+b_{1} \text { PFSM }_{t}+b_{2} \text { Scale }_{t}+b_{3} \mathrm{BIG}_{t}+b_{4} \text { Size }_{t} \\
& +b_{5} \text { Cash }_{t-1}+b_{6} \text { Lev }_{t-1}+\Sigma \text { Year }+\varepsilon
\end{aligned}
$$

Model (1) is used to estimate the normal investment level that companies should have, Model (2) and model (3) take the estimation results of the over-investment degree of the model (1) as dependent variables to test the hypothesis.

$a_{0}$ and $b_{0}$ are constant terms.

$a_{1}, a_{2}, a_{3}, a_{4}, a_{5}, a_{6}, a_{7}, b_{0}, b_{1}, b_{2}, b_{3}, b_{4}, b_{5}, b_{6}$ are coefficients of the respective variables.

$\varepsilon$ is the random error term.

\subsection{Variable Design}

Dependent Variable-Over-investment.

Richardson's model, which can distinguish under-investment from over-investment and measure the level of over-investment, has been widely used by scholars. This paper will also use Richardson's research ideas for reference. Firstly, the appropriate investment level of the year is estimated, and then the positive residual value between the actual investment value of the year and the appropriate investment value is used to quantify the over-investment.

$\mathrm{INV}_{\mathrm{t}}$ represents the investment level, that is, the new investment expenditure for the year, which is the ratio of the net value change of fixed assets, intangible assets and long-term investment to the total assets at the beginning of the year. OverINV $_{t}$ is the level of over-investment in the current year and is represented by a regression residual greater than 0 in model (1).

Independent Variable-Female 
Table 1. Data collecting.

\begin{tabular}{cccc}
\hline & 2017 & 2018 & total \\
\hline Initial Sample (A-share of listed company of SSE) & 895 & 895 & 1790 \\
ExExculude: Financial listed companies & 36 & 36 & 72 \\
Companies with missing data & 59 & 59 & 118 \\
ST, ${ }^{*}$ ST companies & 75 & 75 & 150 \\
Final valid sample & 725 & 725 & 1450 \\
\hline
\end{tabular}

The variables explained here are defined in terms of both "quality" and "quantity". Female $e_{t}$ is used to indicate whether the listed company has a female senior position in the year. If the value is 1 , the value is $0 . \mathrm{PFSM}_{\mathrm{t}}$ is used to indicate the proportion of female employees in the overall high-level scale, which is equal to the number of female seniors divided by the total number of senior executives in Table 2.

\section{Findings and Discussion}

\subsection{Statistical Analysis of Female Top Executives in Chinese Listed Companies}

\subsubsection{Distribution of the Number of Female Senior Staff in the Sample Company}

For Shanghai Stock Exchange A shares (excluding financial industry, ST, ${ }^{\star} \mathrm{ST}$ companies and missing data samples) 725 sample companies in 2017 and 2018 senior staff, including chairman, vice chairman, directors, independent directors, board secretary, The general manager, deputy general manager, financial controller, chief accountant, chief economist, and assistant to the general manager were collected and organized in Figure 1.

As can be seen from the above table and bar chart, the higher the position is, the lower the proportion of women in senior positions, such as chairman, vice chairman and general manager. The proportion of female in these positions is still lower than that of other positions, only $5 \%$. Women hold more than $20 \%$ of the jobs in 2017, including chief financial officers, chief accountants, board secretaries and supervisors. In addition, the proportion of women holding the posts of senior managers is significantly lower than that of deputy managers.

\subsection{Model Empirical Research Results}

\subsubsection{Descriptive Statistics Analysis}

Table 3 shows that $89 \%$ of the company's senior managers have female employees, and the highest proportion of female employees in the company's senior management reaches $50 \%$. The standard deviation of the proportion of female senior executives reached $9.46 \%$, indicating that there was a big difference in the proportion of female senior executives in different companies. This can be explained by the influence of industry characteristics. Female' experience and effective communication with customers are needed to better grasp market dynamics. In the case of the company's average scale of 19.03, the average female 
employment ratio (PFSM) is $13.32 \%$, indicating that there are an average of 2.5 female employees in each company's top ranks, and male are dominant in the top management team.

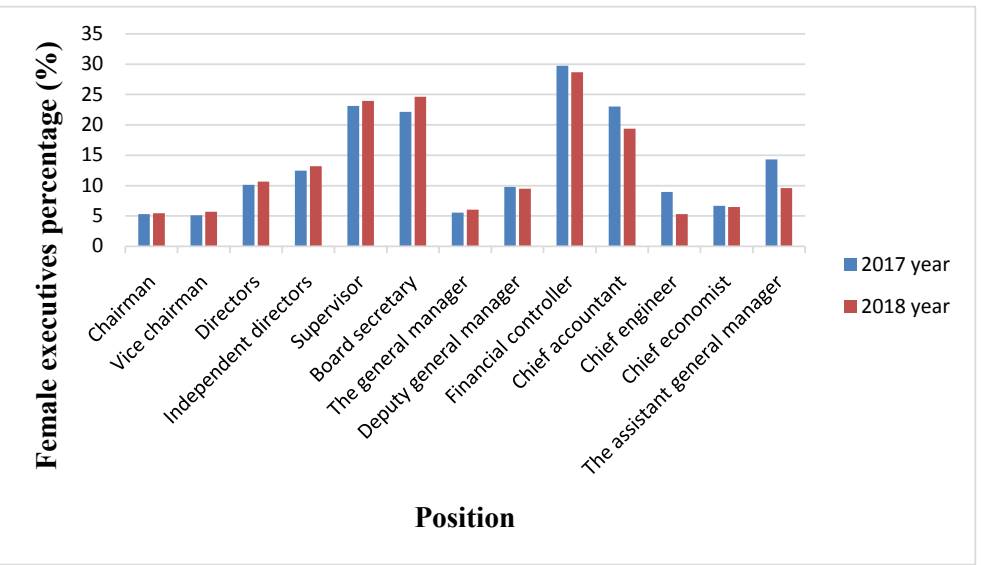

Figure 1. Bar chart of female senior positions in sample companies.

Table 2. Control variables.

\begin{tabular}{|c|c|c|}
\hline $\begin{array}{l}\text { Variable } \\
\text { Symbols }\end{array}$ & Variable Name & Variable Definition \\
\hline Growth & Growth opportunities & Proportion of sales revenue growth at the end of the year \\
\hline Lev & Asset-liability ratio & $\begin{array}{l}\text { The ratio of total liabilities to total assets at the end of the } \\
\text { year }\end{array}$ \\
\hline Cash & Cash holding level & $\begin{array}{l}\text { Cash and cash equivalents at the end of the year/total } \\
\text { assets at the end of the previous year }\end{array}$ \\
\hline Age & Enterprise age & $\begin{array}{l}\text { Years since the company's initial public offering reached } \\
\text { the end of the year }\end{array}$ \\
\hline Size & Company size & The natural logarithm of the company's total assets \\
\hline EPS & Earnings per share & The basic earnings per share \\
\hline Scale & $\begin{array}{l}\text { Top management teams } \\
\text { scale }\end{array}$ & $\begin{array}{l}\text { The natural logarithm of the total number of senior staff } \\
\text { in this year }\end{array}$ \\
\hline BIG & $\begin{array}{l}\text { The shareholding ratio of } \\
\text { the first largest shareholder }\end{array}$ & $\begin{array}{l}\text { The percentage of shares held by the company's largest } \\
\text { shareholder in the middle of the year }\end{array}$ \\
\hline Year & Annual dummy variable & Value is 1 for the sample company in the year \\
\hline
\end{tabular}

Table 3. Descriptive statistics of main variables of the test model.

\begin{tabular}{ccccc}
\hline & Minimum & Maximum & Mean & Std. Deviation \\
\hline Female & 0 & 1 & 0.89 & 0.316 \\
PFSM & 0.000 & 0.500 & 0.13316 & 0.094605 \\
Scale & 10 & 33 & 19.03 & 4.378 \\
BIG & 0.0502 & 0.8635 & 0.395965 & 0.1765921 \\
Size & 19.222051778 & 28.282057972 & 22.9900623244 & 1.457854503636 \\
Cash & 0.00120080852 & 0.88816650507 & 0.142193096094 & 0.11471835218857 \\
OverINV & 0.00220 & 16.30349 & 0.6439324 & 1.63490637 \\
\hline
\end{tabular}




\subsubsection{The Single-Variable Analysis}

Table 4 is a univariate analysis of each variable and the main explanatory variables are tested by Pearson correlation coefficient method. We found that the correlation coefficient between Female and OverINV was significant at the 5\% level, and the correlation coefficient between PFSM and OverINV was significant at the $5 \%$ level, which preliminarily confirmed our hypothesis.

\subsubsection{Collinearity Diagnostics}

It is generally believed that if VIF is no more than 10 , the collinearity between explanatory variables is not strong. The results of collinearity diagnosis indicating that there is no serious collinearity among explanatory variables in each model (all the VIF $<2$ ).

\subsubsection{Regression Analysis}

The regression results show that the regression results show that the asset-liability ratio (Lev) has a significant positive correlation with over-investment at the level of $1 \%$. The higher the level of the company's investment under a high debtto-asset ratio, the more likely it is that over-investment will occur. There is a negative correlation between the scale of top management and over-investment, but the correlation is not significant. The presence of female top management can effectively inhibit the occurrence of the company's over-investment behavior ( $\beta$ $=-0.649, P<0.05)$. So hypothesis 1 is supported.

It can be concluded in Table 6 that the model is significant in the population $(\mathrm{F}=6.274)$, and there is a significant linear relationship between the explained variables and the explanatory variables. The higher the proportion of female senior management, the less likely the occurrence of over-investment behavior of listed companies. The inhibition effect of female senior management on overinvestment behavior of listed companies is greater with the increase of the proportion of female senior management $(\beta=-2.068, P<0.05)$. So hypothesis 2 is supported.

Table 4. Pearson correlation coefficient.

\begin{tabular}{|c|c|c|c|c|c|c|c|c|}
\hline & 1 & 2 & 3 & 4 & 5 & 6 & 7 & 8 \\
\hline 1. Female & 1 & & & & & & & \\
\hline 2. PFSM & $0.501^{* * *}$ & 1 & & & & & & \\
\hline 3. Scale & $-0.117^{\star *}$ & $-0.293^{\star \star \star}$ & 1 & & & & & \\
\hline 4. $\mathrm{BIG}$ & -0.066 & $-0.148^{\star * *}$ & $0.168^{\star * *}$ & 1 & & & & \\
\hline 5. Size & -0.051 & $-0.285^{\star \star \star}$ & $0.429^{\star * *}$ & $0.465^{\star * *}$ & 1 & & & \\
\hline 6. Cash & 0.068 & $0.142^{* * *}$ & $-0.181^{\star * *}$ & -0.043 & $-0.225^{\star * *}$ & 1 & & \\
\hline 7. Lev & -0.029 & $-0.175^{\star \star *}$ & $0.207^{\star * *}$ & $0.093^{*}$ & $0.314^{* * *}$ & $-0.268^{\star * *}$ & 1 & \\
\hline 8. OverINV & $-0.117^{\star *}$ & $-0.096^{\star *}$ & -0.061 & $0.059^{*}$ & $-0.053^{\star *}$ & $0.085^{\star *}$ & $0.194^{\star * *}$ & 1 \\
\hline
\end{tabular}

(Note: $\left.{ }^{*} P<0.1,{ }^{* *} P<0.05,{ }^{* *} P<0.01\right)$. 
Table 5. Regression results of the path model of "the existence of female executives-over-investment".

\begin{tabular}{|c|c|c|c|c|c|c|}
\hline & & & Coefficient & & & \\
\hline & & Unstandardized & & Standardized & & \\
\hline & & Coefficients & & Coefficients & & \\
\hline & Model & B & Std. Error & Beta & $\mathrm{t}$ & Sig. \\
\hline 1 & (Constant) & 3.390 & 1.466 & & 2.312 & 0.021 \\
\hline & Female & -0.649 & 0.259 & -0.125 & -2.503 & 0.013 \\
\hline & Scale & -0.025 & 0.021 & -0.068 & -1.223 & 0.222 \\
\hline & BIG & 0.981 & 0.521 & 0.106 & 1.882 & 0.061 \\
\hline & Size & -0.152 & 0.072 & -0.136 & -2.127 & 0.034 \\
\hline & Cash & 1.828 & 0.747 & 0.128 & 2.448 & 0.015 \\
\hline & Lev & 2.411 & 0.476 & 0.271 & 5.062 & 0.000 \\
\hline & a. Dependent & Jariable: OverINV & & & & \\
\hline & F value: 6.489 & & & & & \\
\hline & $0.309^{\mathrm{a}}$, R Sc & are: 0.096 , Adjust & Square: 0. & & & \\
\hline
\end{tabular}

(Note: Constant-Unstandardized Coefficient-B represents the constant term of the regression model; $\mathrm{t}$ represents the statistic for testing the regression coefficients; Sig. represents the significance level test results in Table 5).

Table 6. Regression results of the path model of "Proportion of Female Top Management-Over Investment".

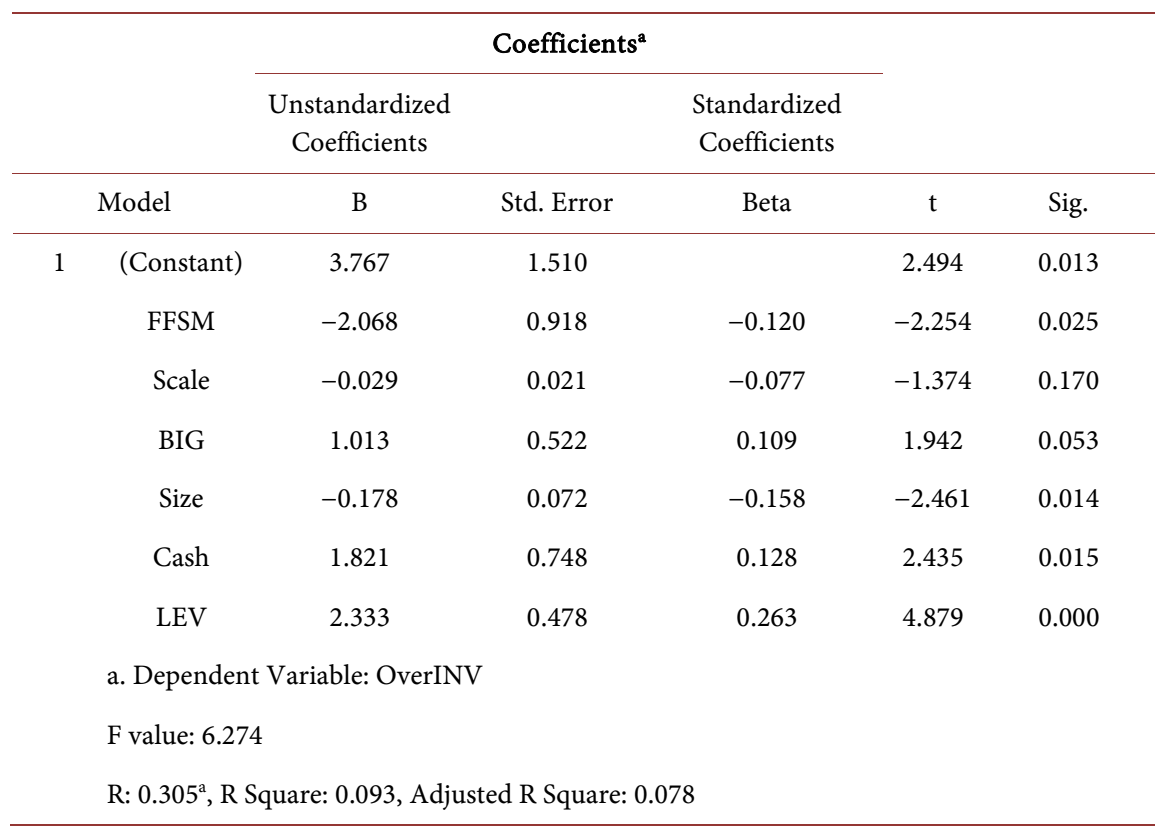

\section{Conclusion and Recommendations}

\subsection{Conclusion}

With the development of economy and the improvement of female's status, more and more women participate in the operation and management of enter- 
prises, and more and more female executives appear in the world's leading enterprises. Many companies attach great importance to the unique advantage of female senior management, and put gender diversity management at the strategic level of the company. However, developing countries do not pay enough attention to it. However, no consensus has been reached on whether female executives have governance functions. By referring to relevant studies of domestic and foreign scholars, this paper measures the over-investment level of listed companies in Shanghai Stock Exchange of China by referring to Richardson's (2006) over-investment residual measurement model. This paper examines the influence of the personal characteristics of executives in listed companies on corporate over-investment behavior, and empirically analyzes the relationship between the gender characteristics of executives and corporate over-investment. Come to the conclusions.

1) Male still occupy the dominant position in the senior management, and the higher the position, the lower the proportion of female senior positions. Female in the top leadership positions are in a disadvantaged position, and there is still a "glass ceiling" effect in female positions.

2) The proportion of women in the positions of finance chief, chief accountant, supervisor, and secretary to the board of directors is quite high compared to other positions. In these positions, it is easier for women to break through the "glass ceiling".

3) Wholesale and retail industries and social service industries are more suitable for female personality traits and more suitable for female careers. These industries have greater opportunities for women to enter the top level and are more conducive to the development of female careers.

4) The empirical research model finds that the presence of female top managers can effectively inhibit the occurrence of over-investment behaviors of companies, and the companies with female top managers are less likely to have over-investment behaviors than those without female top managers.

5) In the over-investment model that introduces the proportion of women in senior positions, after regression analysis, it is found that the proportion of women in high-level positions is significantly negatively correlated with the excessive investment behavior of listed companies. The higher the proportion of female seniors, the less likely it is that listed companies will be over-invested.

\subsection{Recommendations}

At present, China is in the transitional market. As the corporate governance system is still not perfect, with the rapid development of the economy, many companies have the motive of blind expansion, and there are more excessive investment behaviors. The results of this study found that the presence of female executives significantly inhibited the company's excessive investment behavior, and with the increase in the proportion of female high-level, its role is greater. Female executives have a role to play in corporate governance. In the emerging economies, we need to use the power of female's top management to play the 
role of female talents to improve the company's governance structure.

\subsubsection{For Individuals}

Female must play a dual role, housewife, and entrepreneur. It is difficult for them to play these two roles simultaneously way. Female should have a clear understanding of the development of the company they choose and try to choose an industry that is conducive to female career development.

1) Female, whether married or unmarried, continue to learn workplace skills and communication skills at the beginning of their careers. Build confidence, improve core competitiveness, have the courage to perform, and treat work with an objective and fair attitude. Don't be disturbed by the outside world's contempt for women, strive for the top, and have the courage to break the "ceiling" effect. By virtue of their own gender heterogeneity advantages, give play to the strong sense of responsibility of female staff and good self-restraint ability. Actively participate in the company's business activities, integrate into the collective, and strive to make achievements in ordinary positions. Cultivate the consciousness of lifelong learning.

2) As a contemporary college student, we should set up lofty ideals. During the school period, we should work hard to learn professional cultural knowledge. In life, strict self-requirements, participate in social practice more, and cultivate various skills for being an outstanding professional manager in the future. At the same time, strive to improve their academic level and education level. Make contributions to the country

3) Avoid incidents of inequality between men and women, have the courage to happen, and stand up to stop them. Cultivating the concept of equality starts with everyone on their own.

\subsubsection{For Company}

1) Companies need to pay more attention to female at the senior position. The company should desalt the sense of male control at the top management, achieve real equality between male and female in the construction of corporate culture, and realize that the perfect combination of male and female employees will bring greater development to the company.

2) When selecting employees, we should give female and male a fair chance to compete. On the promotion of positions, company should treat ability and strength equally, put aside the sexist belief that men are more suitable for managers, and let the most suitable people be promoted. For potential female managers, training and guidance should be conducted to fully tap their potential and potential, so that they can give full play to their advantages.

3) Create a better working environment for female. In the family, female such as housework and child care are more energetic than male, and female are the main bearers, so that most female feel that their career development is not smooth. For the interruption period of female's marriage and bearing children, special welfare is provided to support. More care of the company will promote 
female's growth, which not only helps the balance of female's family and work, but also makes female's careers better. Women will be more willing to work for such a humanized company.

4) Improve the company system. In the internal system charter of the company, it is necessary to increase the relevant terms and conditions of female executives, and clarify the relevant rights and obligations, and stipulate the appropriate proportion of female personnel in the board of directors and the board of supervisors according to their own development needs. This not only contributes to the reform of the internal structure of the company, but also is an important measure to adapt to economic development and to be in line with international standards.

\subsubsection{For the Government}

1) Formulate laws and regulations to set a minimum gender ratio for the company's talent composition at different levels. We can learn from the Nordic countries and other countries to specify the proportion of female members in the company's top management by laws, and better realize the female participation in the company's various operations and management through the rational construction of the gender structure of the top management.

2) Improve laws and regulations that protect female's rights and interests, from the perspective of tax incentives. The government can provide special benefits to support the interruption of marriage and childbearing.

3) Urgent need to break the gender barrier. The government and the media can promote female's spirit and create a social atmosphere supporting female's employment. In this paper, the author discusses the positive impact that women at the top can bring to corporate governance.

\section{Conflicts of Interest}

The authors declare no conflicts of interest regarding the publication of this paper.

\section{References}

Gao, Y., \& Zhang, X. (2011). Female Directors and Corporate Governance. Human Resource Management, 4, 33-34.

Hambrick, D. C. (1994). Top Management Groups: A Conceptual Integration and Reconsideration of the "Team" Label. Research in Organizational Behaviour, 16, 171-213.

Hambrick, D. C., \& Mason, P. A. (1984). Upper Echelons: The Organization as a Reflection of Its Top Managers. Academy of Management Review, 9, 193-206. https://doi.org/10.5465/amr.1984.4277628

Han, R. (2011). Analysis of the Causes and Countermeasures of Excessive Investment Behavior of Listed Companies in China. Today's Wealth, 10.

He, J., \& Ding, J. (2001). Empirical Analysis of Investment Decision-Making Behavior of Listed Companies. Securities Market Herald, 9, 44-47. https://www.catalyst.org/

Huang, J., \& Kisgen, D. J. (2013). Gender and Corporate Finance: Are Male Executives Overconfident Relative to Female Executives? Journal of Financial Economics, 108, 
822-839. https://doi.org/10.1016/j.jfineco.2012.12.005

Jensen, M. C. (1986). Agency Costs of Free-Cash-Flow, Corporate Finance, and Takeovers. American Economic Review, 76, 323-329.

Jensen, M. C., \& Meckling, W. H. (1976). Theory of the Firm: Managerial Behavior, Agency Costs, and Capital Structure. Journal of Financial Economics, 3, 305-360. https://doi.org/10.1016/0304-405X(76)90026-X

Li, L., Ma, Q., \& Gao, T. (2010). Analysis of the Constraints of Excessive Investment Behavior of Listed Companies. Management Science Academic Edition, 6, 37-44.

Li, X., \& Sun, J. (2008). Empirical Study on the Effect of Corporate Governance on the Excessive Investment of Listed Companies. Journal of Ningxia University, 30, 127-130.

Myers, S. C., \& Majluf, N. S. (1984). Corporate Financing and Investment Decisions When Firms Have Information That Investors Do Not Have. Social Science Electronic Publishing, 13, 187-221. https://doi.org/10.3386/w1396

Pan, M., \& Jin, Y. (2003). Information Asymmetry, Equity System Arrangement and Over-Investment of Listed Companies. Financial Research, 1, 36-45.

Pfeffer, J., \& Salancik, G. R. (1978). The External Control of Organizations: A Resource Dependence Perspective. New York: Harper \& Row.

Richardson, S. (2006). Over-Investment of Free Cash Flow. Review of Accounting Studies, 11, 159-189. https://doi.org/10.1007/s11142-006-9012-1

Richardson, S. A. (2003). Corporate Governance and the Over-Investment of Surplus Cash. Dissertation, Ann Arbor, MI: Michigan University.

Smith, N., Smith, V., \& Verner, M. (2006). Do Women in Top Management Affect Firm Performance? A Panel Study of 2,500 Danish Firms. International Journal of Productivity and Performance Management, 55, 569-593.

https://doi.org/10.1108/17410400610702160

Wolosin, R. J., Sherman, S. J., \& Till, A. (1973). Effects of Cooperation and Competition on Responsibility Attribution after Success and Failure. Journal of Experimental Social Psychology, 9, 220-235. https://doi.org/10.1016/0022-1031(73)90011-5

Zeng, P., \& Wu, Q. (2012). The Impact of Female Executives' Participation on Corporate Technological Innovation: An Empirical Study Based on GEM Companies. Scientific Research, 30, 773-781.

Zhang, N., Guan, Z., \& Guo, Z. (2011). An Empirical Study on the Relationship between Board Characteristics and Bank Performance: Evidence from 14 Listed Banks in China. Economic Survey, 1, 59-62.

Zhang, Z., Liu, Y., \& Yuan, X. (2013). A Study on the Characteristics of Managers' Background, Promotion Incentive and Over-Investment. Nankai Management Review, 4, $32-42$.

Zheng, F. (2010). Large Shareholder Control and Excessive Investment Behavior of Listed Companies. Contemporary Economy, 9, 104-105.

Zuckerman, M. (1994). Behavioral Expressions and Biosocial Bases of Sensation Seeking. Cambridge: Cambridge University Press. 